\title{
Azithromycin Plus Zinc Sulfate Rapidly and Synergistically Suppresses IкB $\alpha$-Mediated In Vitro Human Airway Cell ACE2 Expression for SARS-CoV-2 Entry
}

Chia-Wei Chang ${ }^{1} \dagger$, Ming-Cheng Lee ${ }^{2} \dagger$, Bor-Ru Lin ${ }^{2,3}$, Yen-Pei Lu ${ }^{1}$, Yih-Jen $\mathrm{Hsu}^{2}$, Chun-Yu Chuang ${ }^{4}$, Tsung-Tao Huang ${ }^{1}$, Yin-Kai Chen ${ }^{5,6} *$

${ }^{1}$ Biomedical Platform and Incubation Service Division, Taiwan Instrument Research Institute, National Applied Research Laboratories, Hsinchu, Taiwan.

${ }^{2}$ Department of Internal Medicine, National Taiwan University Hospital, Taipei, Taiwan.

${ }^{3}$ Department of Integrated Diagnostics and Therapeutics, National Taiwan University Hospital, Taipei, Taiwan.

${ }^{4}$ Department of Biomedical Engineering and Environmental Sciences, National Tsing Hua University, Hsinchu, Taiwan.

${ }^{5}$ Graduate Institute of Clinical Medicine, College of Medicine, National Taiwan University, Taipei, Taiwan.

${ }^{6}$ Department of Hematology, National Taiwan University Cancer Center, Taipei, Taiwan.

\section{$\dagger$ Equally contributed to this work.}

\section{*Correspondence to :}

Tsung-Tao Huang, Ph. D.

Biomedical Platform and Incubation Services Division

Taiwan Instrument Research Institute, National Applied Research Laboratories, Hsinchu, Taiwan

3F, 8, Sec. 2, Sheng Yi Rd., Zhubei City, Hsinchu County, 30261, Taiwan

E-mail : tthuang@narlabs.org.tw

Phone: +886-3-6676822 ext 3063

FAX: +886-3-6585676

Yin-Kai, Chen, MD

Department of Hematology, National Taiwan University Cancer Center, Taipei, Taiwan.

No.57, Ln. 155, Sec. 3, Keelung Rd., Da'an Dist., Taipei 106, Taiwan

Email : b8201032@tmu.edu.tw

Phone : +886223220322 ext 53996 


\begin{abstract}
Large-scale efforts have been persistently undertaken for medical prophylaxis and treatment of COVID-19 disasters worldwide. A variety of novel viral spike protein-targeted vaccine preparations have recently been clinically distributed based on accelerated approval. We revisited the early but inconclusive clinical interest in the combination of azithromycin and zinc sulfate repurposing with safety advantages. In vitro proof of concept was provided for rapid and synergistic suppression of ACE2 expression following treatments in human airway cells, Calu-3 and H322M. The two representative ACE2-expressing human airway cells indicate the upper and lower respiratory tracts. Prophylactic and early therapeutic roles of azithromycin combined with zinc are proposed for virus cellular entry prevention potential bridging to effective antibody production.
\end{abstract}

\title{
Running Title
}

Azithromycin Plus Zinc Sulfate Suppresses Airway ACE2 


\section{Introduction}

Cell surface angiotensin-converting enzymes 2 (ACE2) of the respiratory tract is a well-established critical entry of SARS-CoV-2 into infected cells [1-3]. ACE2 mRNA expression was shown to be reduced from tracheobronchial to bronchioloalveolar regions [4]. ACE2 expression was upregulated following viral infection $[5,6]$, interferon exposure $[5,6]$ and smoking $[5,6]$. It has been postulated that hyperactivation of the transcription factor NF- $\mathrm{B}$ following ACE2-mediated viral entry, most likely in nonimmune cells, including lung epithelial cells, resulted in cytokine release syndrome [7]. NF- $\mathrm{kB}$ is a major transcription factor that regulates the genes responsible for innate and adaptive immune responses. Human type II pneumocytes (AT2) are one of the primary targets for SARS-CoV-2 infection [6]. It was shown in an induced pluripotent stem cell-derived AT2 model that NF- $\mathrm{BB}$ signaling was rapidly and persistently upregulated upon SARS-CoV-2 infection [8].

Azithromycin (AZT), a second-generation macrolide with broad spectrum antibacterial activity, has drawn early clinical attention in hot drug repurposing for the recurrence of COVID-19 patients. [9-12] In addition to its antimicrobial activity resulting from bacterial protein synthesis inhibition [13], AZT protects against viral entry into A549 lung cancer cell lines [14] and viral infections of airway epithelial cells through reduced viral replication and increased interferon responses [15-17]. AZT was demonstrated in vivo to suppress NF- $\kappa B$ activation and concomitant

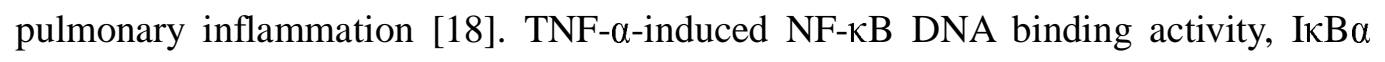
degradation and IL-6/IL-8 release in tracheal cells of human origin were shown to be 
dose-dependently inhibited in vitro following AZT [19].

Zinc is a trace element supplement with clinical benefits in respiratory tract infections [20]._Zinc deficiency prevalence of $26 \%$ was ever reported in a case-control study of adults aged 50 years or older visiting an Ohio outpatient clinic between 2014 and 2017 [21]. Patients with COVID-19 had significantly lower serum zinc levels than normal controls [22]. More complications are developed in COVID-19 patients with zinc deficiency [22]. The prophylactic and therapeutic roles of zinc supplementation are currently under investigation. [23, 24] Prevention of viral entry has been postulated to be a potential mechanism for zinc antiviral actions [20]. Increased NF- $\kappa \mathrm{B}$ DNA binding activity and $\mathrm{I} \kappa \mathrm{B} \alpha$ mRNA expression were reported in lungs from a septic mouse model with zinc deficiency [25].

Short-course AZT has long been clinically used for atypical pneumonia cases with excellent safety and tolerability. Zinc supplementation is a relatively popular companion with vitamin complexes. Here, we showed markedly synergistic ACE2 suppression in two distinct ACE2-expressing human airway cells by combined AZT and zinc treatments. Accordingly, we provided laboratory support to repurpose AZT plus zinc for the early clinical intervention of COVID-19.

\section{Results and Discussion}

Because airway is the primary and lethal target involved in COVID-19, Calu-3, H322M, H522, H460, H1299, and A549 human airway cells were screened for endogenous ACE2 expression. Calu-3, widely used for COVID-19 studies, and H322M were selected for subsequent exploration because of their endogenous ACE2 expression (Fig. 1A). The Calu-3 cells generated from human proximal bronchial adenocarcinoma [26] are characterized by differentiated, functional human airway epithelial cells [27]. These cells were also proposed to be a suitable model for the human nasal mucosa [28]. Bronchoalveolar lavage analyses from COVID-19 patients 
disclosed aberrant macrophage and T cell responses [29] as well as bronchoalveolar immune hyperactivation [30]. Our drug repurposing for the critical bronchoalveolar involvement of COVID-19 was investigated with H322M, a bronchioalveolar cell line, in addition to Calu-3 for proximal airway involvement.

Symptoms, including fever, dyspnea and hypoxia, were rapidly improved following high-dose zinc rescue with different preparations in a consecutive COVID-19 case series. [31] A randomized controlled trial for high-dose intravenous zinc was initiated as adjunctive therapy in SARS-CoV-2-positive critically ill patients [32]. H322M was therefore treated using 24-hour serial doses of 18.75, 37.5, 75, 150 and $300 \mu \mathrm{M}$ ZnSO4 (Zn) (Fig. 1B). Zinc at $300 \mu \mathrm{M}$ was determined for the subsequent drug repurposing combination study because ACE2 expression was potentially decreased following 24-hour treatment (Fig. 1B). $50 \mu \mathrm{M}$ AZT induced significant in vitro anti-rhinoviral activities in normal primary bronchial epithelial cells [15] and those cells from children with cystic fibrosis [16]. Lower in vitro anti-rhinoviral levels of AZT were also reported for bronchial epithelial cells from patients with chronic obstructive lung disease [17]. Accordingly, H322M was treated with 24-hour serial doses of 50, 25, 12.5, 6.25 and 3.125 $\mu \mathrm{M}$ (Fig. 1C). An AZT concentration of $50 \mu \mathrm{M}$ was chosen for the $\mathrm{Zn}$ combination because ACE2 expression was significantly decreased in H322M following 24-hour treatment (Fig. 1C).

This study's most impressive finding was the rapidly suppressed endogenous ACE2 expression of H322M under 24-hour treatment of $300 \mu \mathrm{M} \mathrm{Zn}$ combined with 50 and $25 \mu \mathrm{M}$ AZT (Figs. 2A and 3A). Compared to 50 and $25 \mu \mathrm{M}$ AZT treatments alone, $300 \mu \mathrm{M} Z \mathrm{Zn}$ showed a significant synergistic suppressive effect on ACE2 expression in H322M (Figs. 2A and 3A). ACE2 expression in H322M was further decreased following 48-hour treatment with $\mathrm{Zn}$ and AZT combinations, especially $50 \mu \mathrm{M}$ AZT (Fig. 2B). ACE2 mRNA expression of Calu-3 was significantly reduced following 
24-hour treatment of $300 \mu \mathrm{M} \mathrm{Zn}$ alone and in combination with 50 and $25 \mu \mathrm{M}$ AZT

(Fig. 3C). The markedly suppressive effect on ACE2 protein expression in Calu-3 was found 24 hours later following the suppression of ACE2 mRNA expression. Similar to H322M, 48-hour combination treatment with $300 \mu \mathrm{M}$ and $50 \mu \mathrm{M}$ AZT showed the most suppressive effect on ACE2 expression in Calu-3 (Fig. 2D).

Certain NF- $\mathrm{kB}$ dimeric transcription factors and their activities are tightly repressed

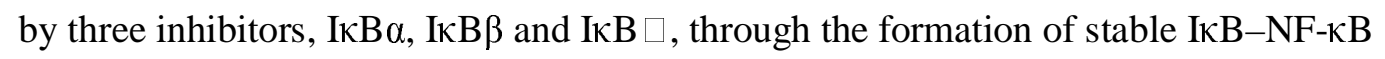
complexes. It was demonstrated that rapid degradation of free $\operatorname{I\kappa } \mathrm{B} \alpha$ is critical for NF- $\kappa \mathrm{B}$ activation [33]. Our H322M-associated results indicated that $\mathrm{Zn}$ and AZT combination treatments altered $\mathrm{I} \kappa \mathrm{B} \alpha$ degradation and contributed to rapid repression of endogenous ACE2 (Figs. 2A, 2B, 3A and 3B). Such synergistic effects were most prominent following 24-hour treatment with $300 \mu \mathrm{M} Z \mathrm{Zn}$ and $50 \mu \mathrm{M}$ AZT (Figs. 2A and $2 \mathrm{~B}$ ). In contrast to the synergistic effect on IкB $\alpha$ degradation in $\mathrm{H} 322 \mathrm{M}, \mathrm{I} \kappa \mathrm{B} \alpha$ expression in Calu-3 was rapidly upregulated following 24-hour treatment of $300 \mu \mathrm{M}$ Zn combined with 50 and $25 \mu \mathrm{M}$ AZT (Figs. 2C and 3D). A similar synergistic ACE2 suppressive effect was most prominent following 48-hour $300 \mu \mathrm{M} \mathrm{Zn}$ treatment combined with $50 \mu \mathrm{M}$ AZT (Figs. 2C and 2D). Accordingly, the underlying mechanisms of $\mathrm{I} \kappa \mathrm{B} \alpha$ involved in ACE2 repression might be cell type specific and worth further investigation.

Membrane-tethered MUC1 belongs to one of the major components of mucus [34]. In vitro MUC1 overexpression was demonstrated to limit influenza A virus (IAV) infection [35]. In vivo MUC1 expression impeded IAV and reduced IAV disease severity [35]. NF- $\mathrm{B}$ activation in vitro via toll-like receptor (TLR) pathways, including TLR 2, 3, 4, 5, 7 and 9, was counteracted by the MUC1 overexpression [36]. There is increasing evidence and a therapeutic interest in TLR pathway modulations for COVID-19 [37-39]. Elevated MUC1 mucin protein levels were found in the 
airway mucus of critically ill COVID-19 patients [40]. Another interesting finding of this study was that MUC1 expression in H322M and Calu-3 cells was most significantly increased following 24 hour treatment with $300 \mu \mathrm{M} \mathrm{Zn}$ alone and a lesser degree after combined treatment with 50 and $25 \mu \mathrm{M}$ AZT (Figs. 4A and 4B).

The largest published retrospective case series reported that early outpatient treatment with zinc plus low-dose hydroxychloroquine and azithromycin significantly reduced the hospitalization rate [41]. Compared with the hydroxychloroquine-based standard of care, the addition of AZT did not show improved clinical outcomes in an open-label multicenter randomized clinical trial performed among patients with severe respiratory COVID-19 in Brazil [42]. Alternatively, large-scale randomized trials did not reveal hydroxychloroquine's clinical benefits of in patients with COVID-19 [43, 44]. Accordingly, the feasible clinical timing and combination choice with AZT remain unelucidated.

A computed model of the AZT- $\mathrm{Zn}^{++}$complex demonstrated its potential against the replication and assembly of SARS-CoV-2 particles. We are the first to present in vitro evidence that Zn combined with AZT rapidly and significantly suppresses endogenous ACE2 expression and increases MUC1 expression in Calu-3 and H322M cells, representative of the human upper and lower respiratory tracts, respectively. Both ACE2 suppression and increased MUC1 expression were consistently demonstrated in the two human airway cells, indicating the prophylactic and early therapeutic potential of AZT and Zn repurposing combination for COVID-19. With threats of mutations located on the viral spike protein [44], we demonstrated a potentially rapid bridging way before effective antibody production after vaccination by suppressing key cellular virus entry. The effective high-dose combination of $\mathrm{Zn}$ and AZT showed here could be translated into a loading dose modality in preclinical studies and clinical trials. 


\section{Materials and Methods}

\section{Cell lines and drug treatments}

The H322M, H522, H460 and A549 human airway cells were courtesy of SLY (National Taiwan University), and the H1299 lung cancer cell line was courtesy of $\mathrm{CCH}$ (National Taiwan University Hospital). Calu-3 human upper airway cells were purchased from the American Type Culture Collection (ATCC) (Manassas, VA, USA). The Calu-3 cells were cultured with MEM (Thermo Fisher Scientific, Waltham, MA, USA) containing 20\% (v/v) fetal bovine serum (Thermo Fisher Scientific), 100 $\mathrm{mM}$ sodium pyruvate, nonessential amino acids and penicillin-streptomycin in a humidified $5 \% \mathrm{CO}_{2}$ atmosphere. The $\mathrm{H} 322 \mathrm{M}$ cells were cultured with RPMI medium (Thermo Fisher Scientific) containing 10\% (v/v) fetal bovine serum (Thermo Fisher Scientific) and penicillin-streptomycin at $37 \square{ }^{\circ} \mathrm{C}$ in a humidified $5 \% \mathrm{CO}_{2}$ atmosphere.

After seeding at a density of $1 \times 10^{6}$ cells per 6-well plate, Calu-3 and H322M cells were incubated for $20 \mathrm{~h}$ at $37{ }^{\circ} \mathrm{C}$ in $5 \% \mathrm{CO}_{2}$. The culture medium was removed and replaced with fresh medium in the presence of (i) $25 \mu \mathrm{M}$ azithromycin (MCE, Monmouth Junction, NJ, USA), (ii) $50 \mu \mathrm{M}$ azithromycin, and (iii) $300 \mu \mathrm{M} \mathrm{Zn}$ (Sigma-Aldrich, ST. Louis, MO, USA), (iv) $300 \mu \mathrm{M} Z \mathrm{Zn}$ and $25 \mu \mathrm{M}$ azithromycin, (v) $300 \mu \mathrm{M} Z \mathrm{Zn}$ and $50 \mu \mathrm{M}$ azithromycin, and incubated for 24 or 48 hours.

\section{RNA isolation}

Total RNA was isolated using the PureLink ${ }^{\mathrm{TM}}$ RNA mini kit (Thermo Fisher Scientific, Waltham, MA, USA) according to the manufacturer's instructions. The RNA concentration and quality were assessed using the Quibit 3.0 Fluorometer (Thermo Fisher Scientific). Total RNA samples were stored at $-80{ }^{\circ} \mathrm{C}$. 


\section{Reverse transcription (RT)}

RT reactions were carried out using the superscript III first strand synthesis system (Thermo Fisher Scientific, Waltham, MA, USA). cDNA was synthesized starting from 2 $\mu \mathrm{g}$ of purified total RNA. The reactions in a final volume of $20 \mu \mathrm{l}$ contained $1 \times$ Buffer, DTT, dNTPs, superscript III RT, and $500 \mathrm{ng}$ oligo(dT). Samples were incubated at $65^{\circ} \mathrm{C}$ for 5 minutes and $50{ }^{\circ} \mathrm{C}$ for 60 minutes, and then the RT enzyme was inactivated by heating to $70^{\circ} \mathrm{C}$ for 15 minutes. cDNA samples were stored at $-20^{\circ} \mathrm{C}$.

\section{Quantitative PCR (qPCR)}

qPCR was carried out with KAPA SYBR ${ }^{\circledR} F A S T$ qPCR Master Mix (Wilmington, MA, USA) in a final volume of $20 \mu \mathrm{l}$, with $0.3 \mu \mathrm{M}$ forward and reverse primer and $1 \mu \mathrm{l}$ of cDNA. Fluorescent detection was performed using the ABI 7500 fast System (Thermo Fisher Scientific) with the following thermal cycling conditions: initial polymerase activation at $95{ }^{\circ} \mathrm{C}$ for 3 minutes, followed by 40 cycles of denaturation at $95^{\circ} \mathrm{C}$ for 3 seconds and annealing/extension at $60^{\circ} \mathrm{C}$ for 30 seconds. After amplification, dissociation (melting) curve analysis was performed to analyze the product melting temperature. Each sample was amplified in triplicate wells. Negative (no template) controls were included in each assay. The results were analyzed using ABI 7500 Fast System Software. The threshold cycle $(\mathrm{Ct})$ at which the amount of amplified target reached a fixed threshold was determined. Relative expression was calculated using the $2^{-\Delta \Delta C a}$ method. The results were analyzed and are shown as the fold change relative to each control group.

\begin{tabular}{llc}
\hline Gene & \multicolumn{1}{c}{ Primer sequences $\left(5^{\prime} \rightarrow 3^{\prime}\right)$} & $\begin{array}{c}\text { Product } \\
\text { size }(\mathrm{bp})\end{array}$ \\
\hline RPLPO & F: TGGTCATCCAGCAGGTGTTCGA & 119 \\
& R: ACAGACACTGGCAACATTGCGG & \\
GAPDH & F: GAAGGTGAAGGTCGGAGT & 172 \\
ACE2 & R: GAAGATGGTGATGGGATTTC & 238
\end{tabular}


R: GGCTGCAGAAAGTGACATGA

IKB $\alpha$

F: GAAGTGATCCGCCAGGTGAA

R: CTGCTCACAGGCAAGGTGTA

MUC1

F: CCTACCATCCTATGAGCGAGTAC

R: GCTGGGTTTGTGTAAGAGAGGC

189

136

\section{Table 1. Primers used for aPCR.}

\section{Western blot}

Cells were scraped with lysis buffer (1\% Triton X-100, 20 $\square \mathrm{mM}$ Tris pH 7.4, $150 \square \mathrm{mM} \mathrm{NaCl}$, and protease inhibitors) on an ice tray, and cell lysates were subjected to western blot analysis. Protein samples were first separated by SDS-PAGE and then transferred to a PVDF membrane. Primary antibodies were applied to detect specific protein expression, followed by incubation with appropriate HRP-conjugated secondary antibodies. Protein signals were developed using an enhanced chemiluminescence reagent (Biomate, Taiwan) and detected by a BIO-RAD ChemiDoc $^{\mathrm{TM}}$ MP imaging system (BIO-RAD, Hercules, CA, USA). Western blots were carried out with ACE-2 antibody (Bioss, Woburn, MA, USA), IKB- $\alpha$ antibody (Santa Cruz, Dallas, TX, USA) and PARP antibody (Cell Signaling, Danvers, MA, USA); $\alpha$-tubulin antibody (Novus, Littleton, CO, USA) was used as a loading control.

\section{Statistical analysis}

For statistical analysis, the mean and standard errors were calculated by using GraphPad Prism software version 9 (GraphPad Software Inc., San Diego, CA, USA). Student's t-tests were used to determine significant differences between two experimental conditions. Data were presented as mean + SEM.

\section{Author contributions}

YKC, TTH, MCL and BRL conceived and designed the research; CWC and YJH performed the experiments; CWC and YKC wrote the manuscript and generated the 
illustrations. TTH, YKC, BRL, YPL and CYC reviewed and edited the manuscript; All authors read and approved the final manuscript.

\section{Acknowledgments}

We are grateful to Ann-Lii Cheng (Dean of National Taiwan University Cancer Center) and Dr. Ming-Hua Shiao, Dr. Yao-Joe Joseph Yang (Chiefs of Taiwan Instrument Research Institute, National Applied Research Laboratories) for organization and coordination between the groups. We thank staff of the Second Core Lab, Department of Medical Research, National Taiwan University Hospital for technical support during the study. We thank Chao-Chi Ho (National Taiwan University Hospital) for technical support of lung cancer cell lines.

\section{Competing Interests}

Disclosures: The authors declare no competing interests exist. 


\section{Reference}

1 Zhou, P., Yang, X. L., Wang, X. G., Hu, B., Zhang, L., Zhang, W., Si, H. R., Zhu, Y., Li, B., Huang, C. L., et al. 2020 A pneumonia outbreak associated with a new coronavirus of probable bat origin. Nature. 579, 270-273. (10.1038/s41586-020-2012-7)

2 Hoffmann, M., Kleine-Weber, H., Schroeder, S., Kruger, N., Herrler, T., Erichsen, S., Schiergens, T. S., Herrler, G., Wu, N. H., Nitsche, A., et al. 2020 SARS-CoV-2 Cell Entry Depends on ACE2 and TMPRSS2 and Is Blocked by a Clinically Proven Protease Inhibitor. Cell. 181, 271-280 e278. (10.1016/j.cell.2020.02.052) 3 Walls, A. C., Park, Y. J., Tortorici, M. A., Wall, A., McGuire, A. T., Veesler, D. 2020 Structure, Function, and Antigenicity of the SARS-CoV-2 Spike Glycoprotein. Cell. 181, 281-292 e286. (10.1016/j.cell.2020.02.058)

4 Zhang, H., Rostami, M. R., Leopold, P. L., Mezey, J. G., O'Beirne, S. L., Strulovici-Barel, Y., Crystal, R. G. 2020 Expression of the SARS-CoV-2 ACE2 Receptor in the Human Airway Epithelium. Am J Respir Crit Care Med. 202, 219-229.

(10.1164/rccm.202003-05410C)

5 Smith, J. C., Sausville, E. L., Girish, V., Yuan, M. L., Vasudevan, A., John, K. M., Sheltzer, J. M. 2020 Cigarette Smoke Exposure and Inflammatory Signaling Increase the Expression of the SARS-CoV-2 Receptor ACE2 in the Respiratory Tract. Dev Cell. 53, 514-529 e513. (10.1016/j.devcel.2020.05.012)

6 Hou, Y. J., Okuda, K., Edwards, C. E., Martinez, D. R., Asakura, T., Dinnon, K. H., 3rd, Kato, T., Lee, R. E., Yount, B. L., Mascenik, T. M., et al. 2020 SARS-CoV-2 Reverse Genetics Reveals a Variable Infection Gradient in the Respiratory Tract. Cell. 182, 429-446 e414. (10.1016/j.cell.2020.05.042)

7 Hirano, T., Murakami, M. 2020 COVID-19: A New Virus, but a Familiar Receptor and Cytokine Release Syndrome. Immunity. 52, 731-733.

(10.1016/j.immuni.2020.04.003)

8 Huang, J., Hume, A. J., Abo, K. M., Werder, R. B., Villacorta-Martin, C., Alysandratos, K. D., Beermann, M. L., Simone-Roach, C., Lindstrom-Vautrin, J., Olejnik, J., et al. 2020 
SARS-CoV-2 Infection of Pluripotent Stem Cell-Derived Human Lung Alveolar Type 2 Cells Elicits a Rapid Epithelial-Intrinsic Inflammatory Response. Cell Stem Cell. (10.1016/j.stem.2020.09.013)

9 Gautret, P., Lagier, J. C., Parola, P., Hoang, V. T., Meddeb, L., Sevestre, J., Mailhe, M., Doudier, B., Aubry, C., Amrane, S., et al. 2020 Clinical and microbiological effect of a combination of hydroxychloroquine and azithromycin in 80 COVID-19 patients with at least a six-day follow up: A pilot observational study. Travel Med Infect Dis. 34, 101663. (10.1016/j.tmaid.2020.101663)

10 Rosenberg, E. S., Dufort, E. M., Udo, T., Wilberschied, L. A., Kumar, J., Tesoriero, J., Weinberg, P., Kirkwood, J., Muse, A., DeHovitz, J., et al. 2020 Association of Treatment With Hydroxychloroquine or Azithromycin With In-Hospital Mortality in Patients With COVID-19 in New York State. JAMA. (10.1001/jama.2020.8630) 11 Cavalcanti, A. B., Zampieri, F. G., Rosa, R. G., Azevedo, L. C. P., Veiga, V. C., Avezum, A., Damiani, L. P., Marcadenti, A., Kawano-Dourado, L., Lisboa, T., et al. 2020 Hydroxychloroquine with or without Azithromycin in Mild-to-Moderate Covid-19. N Engl J Med. (10.1056/NEJMoa2019014)

12 Lagier, J. C., Million, M., Gautret, P., Colson, P., Cortaredona, S., Giraud-Gatineau, A., Honore, S., Gaubert, J. Y., Fournier, P. E., Tissot-Dupont, H., et al. 2020 Outcomes of 3,737 COVID-19 patients treated with hydroxychloroquine/azithromycin and other regimens in Marseille, France: A retrospective analysis. Travel Med Infect Dis. 101791. (10.1016/j.tmaid.2020.101791)

13 Tenson, T., Lovmar, M., Ehrenberg, M. 2003 The mechanism of action of macrolides, lincosamides and streptogramin $B$ reveals the nascent peptide exit path in the ribosome. J Mol Biol. 330, 1005-1014. (10.1016/s0022-2836(03)00662-4) 14 Tran, D. H., Sugamata, R., Hirose, T., Suzuki, S., Noguchi, Y., Sugawara, A., Ito, F., Yamamoto, T., Kawachi, S., Akagawa, K. S., et al. 2019 Azithromycin, a 15-membered macrolide antibiotic, inhibits influenza $A(H 1 N 1) p d m 09$ virus infection by interfering with virus internalization process. J Antibiot (Tokyo). 72, 759-768.

(10.1038/s41429-019-0204-x)

15 Gielen, V., Johnston, S. L., Edwards, M. R. 2010 Azithromycin induces anti-viral responses in bronchial epithelial cells. Eur Respir J. 36, 646-654.

(10.1183/09031936.00095809)

16 Schogler, A., Kopf, B. S., Edwards, M. R., Johnston, S. L., Casaulta, C., Kieninger, E., Jung, A., Moeller, A., Geiser, T., Regamey, N., et al. 2015 Novel antiviral properties of azithromycin in cystic fibrosis airway epithelial cells. Eur Respir J. 45, 428-439.

(10.1183/09031936.00102014)

17 Menzel, M., Akbarshahi, H., Bjermer, L., Uller, L. 2016 Azithromycin induces anti-viral effects in cultured bronchial epithelial cells from COPD patients. Sci Rep. 6, 
28698. (10.1038/srep28698)

18 Stellari, F. F., Sala, A., Donofrio, G., Ruscitti, F., Caruso, P., Topini, T. M., Francis, K. P., Li, X., Carnini, C., Civelli, M., et al. 2014 Azithromycin inhibits nuclear factor-kappaB activation during lung inflammation: an in vivo imaging study. Pharmacol Res Perspect. 2, e00058. (10.1002/prp2.58)

19 Aghai, Z. H., Kode, A., Saslow, J. G., Nakhla, T., Farhath, S., Stahl, G. E., Eydelman, R., Strande, L., Leone, P., Rahman, I. 2007 Azithromycin suppresses activation of nuclear factor-kappa B and synthesis of pro-inflammatory cytokines in tracheal aspirate cells from premature infants. Pediatr Res. 62, 483-488.

(10.1203/PDR.0b013e318142582d)

20 Wessels, I., Rolles, B., Rink, L. 2020 The Potential Impact of Zinc Supplementation on COVID-19 Pathogenesis. Front Immunol. 11, 1712. (10.3389/fimmu.2020.01712) 21 Gau, J. T., Ebersbacher, C., Kao, T. C. 2020 Serum Zinc Concentrations of Adults in an Outpatient Clinic and Risk Factors Associated With Zinc Deficiency. J Am

Osteopath Assoc. 120, 796-805. (10.7556/jaoa.2020.138)

22 Jothimani, D., Kailasam, E., Danielraj, S., Nallathambi, B., Ramachandran, H., Sekar, P., Manoharan, S., Ramani, V., Narasimhan, G., Kaliamoorthy, I., et al. 2020 COVID-19: Poor outcomes in patients with zinc deficiency. Int J Infect Dis. 100, 343-349.

(10.1016/j.ijid.2020.09.014)

23 Kumar, A., Kubota, Y., Chernov, M., Kasuya, H. 2020 Potential role of zinc supplementation in prophylaxis and treatment of COVID-19. Med Hypotheses. 144, 109848. (10.1016/j.mehy.2020.109848)

24 Sahebnasagh, A., Saghafi, F., Avan, R., Khoshi, A., Khataminia, M., Safdari, M., Habtemariam, S., Ghaleno, H. R., Nabavi, S. M. 2020 The prophylaxis and treatment potential of supplements for COVID-19. Eur J Pharmacol. 887, 173530.

(10.1016/j.ejphar.2020.173530)

25 Bao, S., Liu, M. J., Lee, B., Besecker, B., Lai, J. P., Guttridge, D. C., Knoell, D. L. 2010 Zinc modulates the innate immune response in vivo to polymicrobial sepsis through regulation of NF-kappaB. Am J Physiol Lung Cell Mol Physiol. 298, L744-754. (10.1152/ajplung.00368.2009)

26 Sibinovska, N., Zakelj, S., Roskar, R., Kristan, K. 2020 Suitability and functional characterization of two Calu-3 cell models for prediction of drug permeability across the airway epithelial barrier. Int J Pharm. 585, 119484.

(10.1016/j.ijpharm.2020.119484)

27 Foster, K. A., Avery, M. L., Yazdanian, M., Audus, K. L. 2000 Characterization of the Calu-3 cell line as a tool to screen pulmonary drug delivery. Int J Pharm. 208, 1-11. (10.1016/s0378-5173(00)00452-x)

28 Inoue, D., Furubayashi, T., Tanaka, A., Sakane, T., Sugano, K. 2020 Quantitative 
estimation of drug permeation through nasal mucosa using in vitro membrane permeability across Calu-3 cell layers for predicting in vivo bioavailability after intranasal administration to rats. Eur J Pharm Biopharm. 149, 145-153.

(10.1016/j.ejpb.2020.02.004)

29 Liao, M., Liu, Y., Yuan, J., Wen, Y., Xu, G., Zhao, J., Cheng, L., Li, J., Wang, X., Wang, F., et al. 2020 Single-cell landscape of bronchoalveolar immune cells in patients with COVID-19. Nat Med. 26, 842-844. (10.1038/s41591-020-0901-9)

30 Xu, G., Qi, F., Li, H., Yang, Q., Wang, H., Wang, X., Liu, X., Zhao, J., Liao, X., Liu, Y., et al. 2020 The differential immune responses to COVID-19 in peripheral and lung revealed by single-cell RNA sequencing. Cell Discov. 6, 73.

(10.1038/s41421-020-00225-2)

31 Finzi, E. 2020 Treatment of SARS-CoV-2 with high dose oral zinc salts: A report on four patients. Int J Infect Dis. 99, 307-309. (10.1016/j.ijid.2020.06.006) 32 Perera, M., El Khoury, J., Chinni, V., Bolton, D., Qu, L., Johnson, P., Trubiano, J., McDonald, C. F., Jones, D., Bellomo, R., et al. 2020 Randomised controlled trial for high-dose intravenous zinc as adjunctive therapy in SARS-CoV-2 (COVID-19) positive critically ill patients: trial protocol. BMJ Open. 10, e040580.

(10.1136/bmjopen-2020-040580)

33 Mathes, E., O'Dea, E. L., Hoffmann, A., Ghosh, G. 2008 NF-kappaB dictates the degradation pathway of IkappaBalpha. EMBO J. 27, 1357-1367.

(10.1038/emboj.2008.73)

34 Pelaseyed, T., Bergstrom, J. H., Gustafsson, J. K., Ermund, A., Birchenough, G. M., Schutte, A., van der Post, S., Svensson, F., Rodriguez-Pineiro, A. M., Nystrom, E. E., et al. 2014 The mucus and mucins of the goblet cells and enterocytes provide the first defense line of the gastrointestinal tract and interact with the immune system.

Immunol Rev. 260, 8-20. (10.1111/imr.12182)

35 McAuley, J. L., Corcilius, L., Tan, H. X., Payne, R. J., McGuckin, M. A., Brown, L. E. 2017 The cell surface mucin MUC1 limits the severity of influenza A virus infection.

Mucosal Immunol. 10, 1581-1593. (10.1038/mi.2017.16)

36 Ueno, K., Koga, T., Kato, K., Golenbock, D. T., Gendler, S. J., Kai, H., Kim, K. C. 2008 MUC1 mucin is a negative regulator of toll-like receptor signaling. Am J Respir Cell Mol Biol. 38, 263-268. (10.1165/rcmb.2007-0336RC) 37 Poulas, K., Farsalinos, K., Zanidis, C. 2020 Activation of TLR7 and Innate Immunity as an Efficient Method Against COVID-19 Pandemic: Imiquimod as a Potential Therapy. Front Immunol. 11, 1373. (10.3389/fimmu.2020.01373) 38 Patra, R., Chandra Das, N., Mukherjee, S. 2020 Targeting human TLRs to combat COVID-19: A solution? J Med Virol. (10.1002/jmv.26387)

39 Onofrio, L., Caraglia, M., Facchini, G., Margherita, V., Placido, S., Buonerba, C. 
2020 Toll-like receptors and COVID-19: a two-faced story with an exciting ending. Future Sci OA. 6, FSO605. (10.2144/fsoa-2020-0091)

40 Lu, W., Liu, X., Wang, T., Liu, F., Zhu, A., Lin, Y., Luo, J., Ye, F., He, J., Zhao, J., et al. 2020 Elevated MUC1 and MUC5AC mucin protein levels in airway mucus of critical ill COVID-19 patients. J Med Virol. (10.1002/jmv.26406)

41 Derwand, R., Scholz, M., Zelenko, V. 2020 COVID-19 outpatients: early risk-stratified treatment with zinc plus low-dose hydroxychloroquine and azithromycin: a retrospective case series study. Int J Antimicrob Agents. 56, 106214. (10.1016/j.ijantimicag.2020.106214)

42 Furtado, R. H. M., Berwanger, O., Fonseca, H. A., Correa, T. D., Ferraz, L. R., Lapa, M. G., Zampieri, F. G., Veiga, V. C., Azevedo, L. C. P., Rosa, R. G., et al. 2020 Azithromycin in addition to standard of care versus standard of care alone in the treatment of patients admitted to the hospital with severe COVID-19 in Brazil (COALITION II): a randomised clinical trial. Lancet. 396, 959-967.

(10.1016/S0140-6736(20)31862-6)

43 Self, W. H., Semler, M. W., Leither, L. M., Casey, J. D., Angus, D. C., Brower, R. G., Chang, S. Y., Collins, S. P., Eppensteiner, J. C., Filbin, M. R., et al. 2020 Effect of Hydroxychloroquine on Clinical Status at 14 Days in Hospitalized Patients With COVID-19: A Randomized Clinical Trial. JAMA. 324, 2165-2176.

(10.1001/jama.2020.22240) 44 Group, R. C., Horby, P., Mafham, M., Linsell, L., Bell, J. L., Staplin, N., Emberson, J. R., Wiselka, M., Ustianowski, A., Elmahi, E., et al. 2020 Effect of Hydroxychloroquine in Hospitalized Patients with Covid-19. N Engl J Med. 383, 2030-2040.

(10.1056/NEJMoa2022926) 


\section{Figure Legends}

Figure 1 Azithromycin (AZT) but not ZnSO4 (Zn) treatment alone decreased endogenous ACE2 expression in the human lower airway H322M cells. (A) Endogenous ACE2 expression was screened by Western blot using beta-actin as a loading control. ACE2-expressing Calu-3 and H322M cell lines were selected for subsequent exploration. (B) H322M cells were treated with serial concentrations of Zn $(0,18.75,37.5,75,150$ and $300 \mu \mathrm{M})$ for 24 hours, and total RNA was collected for ACE2 quantitation by real-time qRT-PCR assays. The data were normalized to GAPDH expression and presented as the mean \pm SEM $(\mathrm{n}=3)$. ACE2 expression was potentially decreased under 24-hour treatment with $300 \mu \mathrm{M} \mathrm{Zn}$. This concentration was determined for combination treatment with AZT. (C) H322M cells were treated with a concentration series of $\operatorname{AZT}(0,3.125,3.25,12.5,25$ and $50 \mu \mathrm{M})$ for 24 hours, and total RNA was collected for ACE2 quantitation by real-time qRT-PCR assays. The data were normalized to GAPDH expression and presented as the mean \pm SEM ( $\mathrm{n}=$ 3). ( $* * \mathrm{p}=0.001$ to 0.01$)$. ACE2 expression was significantly decreased under 24-hour treatment with $50 \mu \mathrm{M}$ AZT. This concentration was adopted for combination treatment with $\mathrm{Zn}$.

Figure 2 Endogenous ACE2 expression in H322M and Calu-3 cells was markedly 


\title{
suppressed by $\mathrm{Zn}$ and in combination with AZT in a time- and dose-dependent
}

\author{
manner. (A and B) H322M cells were treated with 25, $50 \mu \mathrm{M}$ AZT and $300 \mu \mathrm{M} \mathrm{Zn}$ in
} combination for 24 (A) and 48 (B) hours. Treated cells were lysed for Western blot analysis of ACE2 and PARP with $\alpha$-actin as a loading control. ACE2 expression was suppressed without detectable cleaved PARP by $\mathrm{Zn}$ alone and synergistically with AZT in a time- and dose-dependent manner. IKB- $\alpha$ expression was obviously increased following 24 hours of treatment with $300 \mu \mathrm{M} \mathrm{Zn}$ combined with $50 \mu \mathrm{M}$ AZT. (C and D) Calu-3 cells were treated with 25, $50 \mu \mathrm{M}$ AZT and $300 \mu \mathrm{M} \mathrm{Zn}$ in combination for 24 (C) and 48 (D) hours. Compared to H322M treated in the same ways, ACE2 expression was suppressed without detectable cleaved PARP by $\mathrm{Zn}$ alone and synergistically with AZT in a more time-dependent manner. Similarly, IKB- $\alpha$ expression was obviously increased following 24 hours of treatment with $300 \mu \mathrm{M} \mathrm{Zn}$ combined with $50 \mu \mathrm{M}$ AZT.

Figure 3 Endogenous ACE2 and IKBa expression was synergistically regulated by combined treatments of $\mathbf{Z n}$ and AZT. (A and B) H322M cells were treated with 25, $50 \mu \mathrm{M}$ AZT and $300 \mu \mathrm{M} \mathrm{Zn}$ in combination for 24 hours. Total RNA was collected for $A C E 2$ (A) and $I K B \alpha(\mathrm{B})$ quantitation by real-time qRT-PCR assays. The data were normalized to GAPDH expression and presented as the mean \pm SEM ( $n=$ 3). $(* \mathrm{p}=0.01$ to $0.05, * * \mathrm{p}=0.001$ to $0.01, * * * \mathrm{p}=0.0001$ to 0.001 and $* * * * \mathrm{p}=<$ 0.0001). Compared to the control and AZT alone, $300 \mu \mathrm{M} \mathrm{Zn}$ synergistically decreased $A C E 2$ and $I K B \alpha$ expression with 25 and $50 \mu \mathrm{M}$ AZT treatments, respectively. (C and D) Calu-3 cells were treated with 25, $50 \mu \mathrm{M}$ AZT and $300 \mu \mathrm{M}$ $\mathrm{Zn}$ in combination for 24 hours. Total RNA was collected for ACE2 (A) and IKB $(\mathrm{B})$ quantitation by real-time qRT-PCR assays. The data were normalized to 
GAPDH/RPLP0 expression for H322M/Calu-3 cells respectively and presented as the mean $\pm \operatorname{SEM}(\mathrm{n}=3) .\left({ }^{*} \mathrm{p}=0.01\right.$ to $0.05, * * \mathrm{p}=0.001$ to $0.01, * * * \mathrm{p}=0.0001$ to 0.001 and $* * * * \mathrm{p}=<0.0001)$. Zn showed a similar synergistic suppressive effect on ACE2 expression in AZT treated Calu-3 cells. Conversely, IKB $\alpha$ expression was synergistically upregulated following 25 and $50 \mu \mathrm{M}$ AZT treatments combined with $300 \mu \mathrm{M} Z \mathrm{Zn}$ compared to AZT alone.

Figure 4 Endogenous MUC1 expression was significantly increased by Zn treatment alone and to a lesser degree in combination with AZT. H322M (A) and Calu-3 (B) cells were treated with $25,50 \mu \mathrm{M}$ AZT and $300 \mu \mathrm{M} \mathrm{Zn}$ in combination for 24 hours. Total RNA was collected for MUC1 quantitation by real-time qRT-PCR assays. The data were normalized to GAPDH/RPLP0 expression for H322M/Calu-3 cells respectively and are presented as the mean $\pm \operatorname{SEM}(n=3) .(* \mathrm{p}=0.01$ to $0.05, * *$ $\mathrm{p}=0.001$ to $0.01, * * * \mathrm{p}=0.0001$ to 0.001 and $* * * * \mathrm{p}=<0.0001)$. Compared to the control, MUC1 expression was significantly increased following $300 \mu \mathrm{M} \mathrm{Zn}$ treatment alone and to a lesser degree combined with AZT in H322M and Calu-3 cells. In H322M, MUC1 expression was synergistically increased following $50 \mu \mathrm{M}$ AZT treatments combined with $300 \mu \mathrm{M}$ Zn compared to AZT alone. In Calu-3 cells, MUC1 expression was synergistically increased following 25 and $50 \mu \mathrm{M}$ AZT treatments combined with $300 \mu \mathrm{M}$ Zn compared to AZT alone. 


\section{A. Baseline ACE2 expression}

\begin{tabular}{|c|c|c|c|c|c|c|}
\hline & Calu-3 & H322M & H522 & H460 & H1299 & A549 \\
\hline ACE2 & & & & \\
\hline B-actin & & & \\
\hline
\end{tabular}

B. Zn Dosing, H322M

C. AZT Dosing, H322M
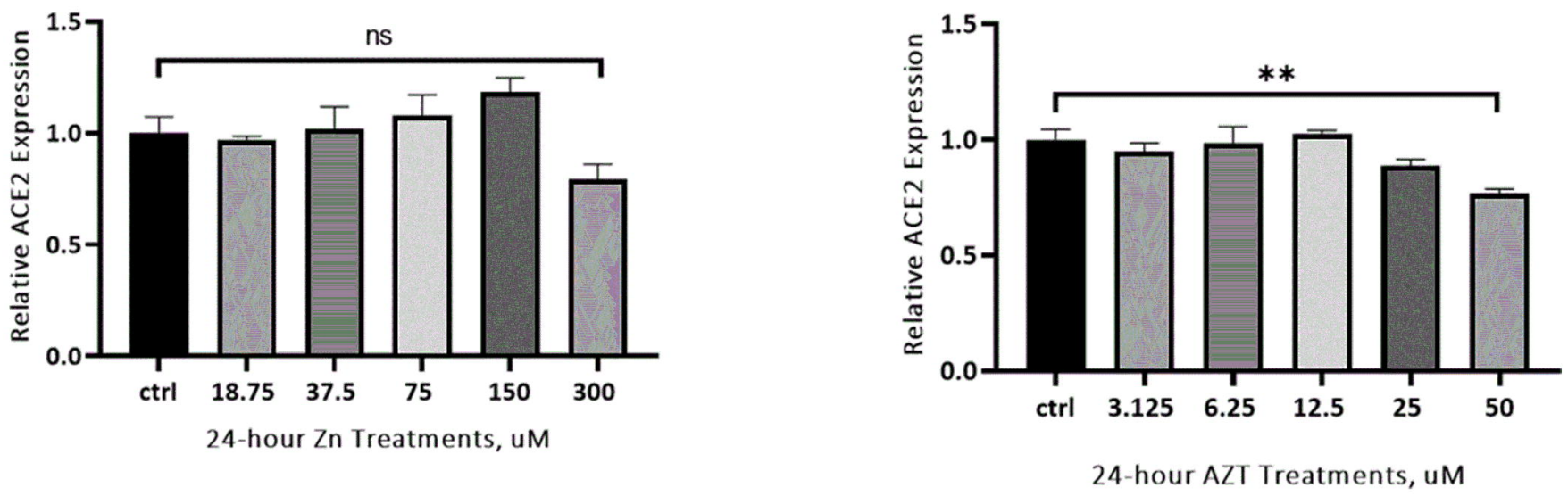
A. H322M, 24-hour Treatments

\begin{tabular}{|c|c|c|c|c|c|c|}
\hline $\begin{array}{c}Z n, u M \\
A Z T, u M\end{array}$ & - & 25 & 50 & $\begin{array}{c}300 \\
-\end{array}$ & $\begin{array}{c}300 \\
25\end{array}$ & $\begin{array}{c}300 \\
50\end{array}$ \\
\hline ACE2 & & & - & $=$ & - & - \\
\hline$\alpha$-tubulin & & & & & & \\
\hline $\mid K B \alpha$ & - & $=$ & rom & rree & 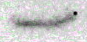 & - \\
\hline $\begin{array}{l}\text { fPARP } \\
\text { CPARP }\end{array}$ & & & & & & \\
\hline$\alpha$-tubulin & & & & & & \\
\hline
\end{tabular}

C. Calu-3, 24-hour Treatment

$\mathrm{Zn}, \mathrm{UM}$
$\mathrm{AZT,}, \mathrm{uM}$
$\mathrm{ACE2}$

B. H322M, 48-hour Treatment

\begin{tabular}{|c|c|c|c|c|c|c|}
\hline $\begin{array}{l}\mathrm{Zn}, \mathrm{uM} \\
\mathrm{AZT}, \mathrm{uM}\end{array}$ & - & 25 & $\begin{array}{c}- \\
50\end{array}$ & $\begin{array}{c}300 \\
-\end{array}$ & $\begin{array}{c}300 \\
25\end{array}$ & $\begin{array}{c}300 \\
50\end{array}$ \\
\hline ACE2 & $\longrightarrow$ & $\longrightarrow$ & $\longrightarrow$ & $=$ & terertiter & 20 \\
\hline$\alpha$-tubulin & & & & & & \\
\hline$I K B \alpha$ & - & - & $\longrightarrow$ & - & $\longrightarrow$ & + \\
\hline $\begin{array}{l}\text { fPARP } \\
\text { CPARP }\end{array}$ & & & & & & \\
\hline$\alpha$-tubulin & & & & & & \\
\hline
\end{tabular}

D. Calu-3, 48-hour Treatment

\begin{tabular}{|c|c|c|c|c|c|c|}
\hline $\begin{array}{c}Z n, u M \\
A Z T, u M\end{array}$ & - & - & 50 & $\begin{array}{c}300 \\
-\end{array}$ & $\begin{array}{c}300 \\
25\end{array}$ & $\begin{array}{c}300 \\
50\end{array}$ \\
\hline ACE2 & $\longrightarrow$ & & 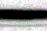 & expents & mosesin: & menestions \\
\hline \multicolumn{7}{|l|}{$\alpha$-tubulin } \\
\hline $\mid K B \alpha$ & $\longrightarrow$ & $\square$ & & 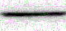 & & \\
\hline $\begin{array}{l}\text { fPARP } \\
\text { CPARP }\end{array}$ & $\longrightarrow$ & & & 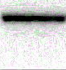 & & \\
\hline$\alpha$-tubulin & & & & & & \\
\hline
\end{tabular}


A. ACE2 expression, $\mathrm{H} 322 \mathrm{M}$

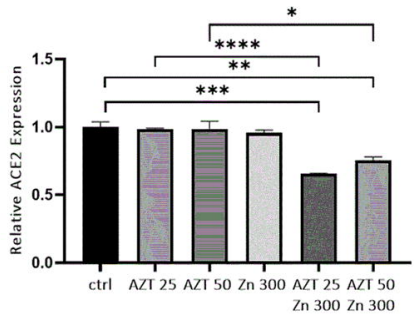

24-hour Treatments, uM

C. ACE2 expression, Calu-3

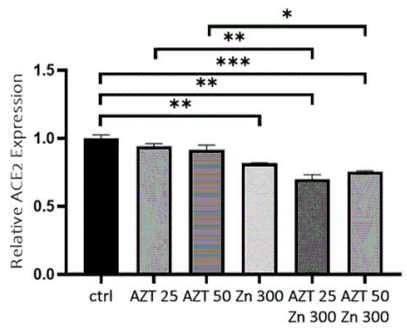

24-hour Treatments, uM
B. IKBalpha expression, H322M

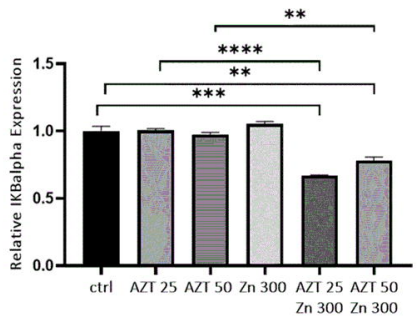

24-hour Treatments, uM

D. IKBalpha expression, Calu-3

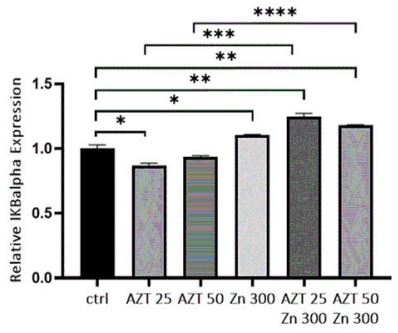

24-hour Treatments, uM 
A. $\mathrm{H} 322 \mathrm{M}$

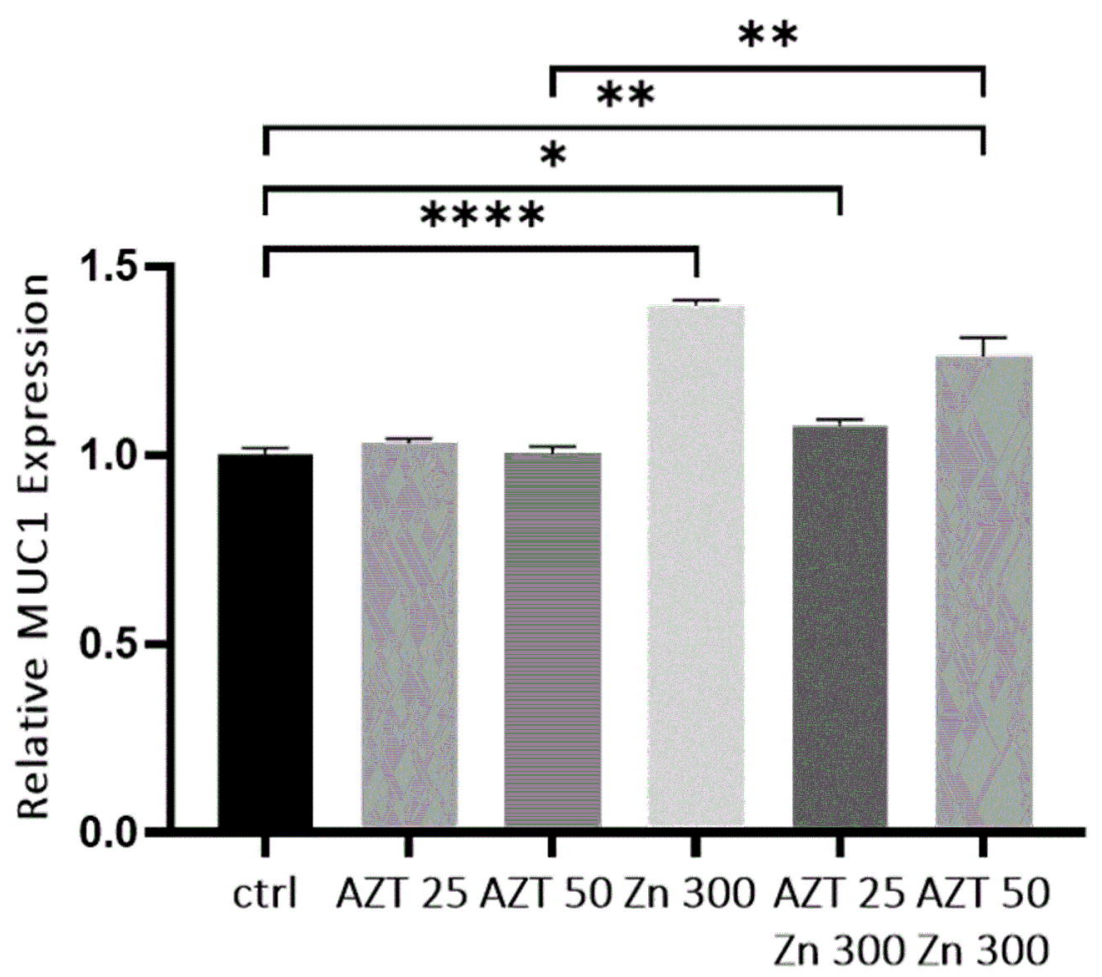

24-hour Treatments, uM
B. Calu-3

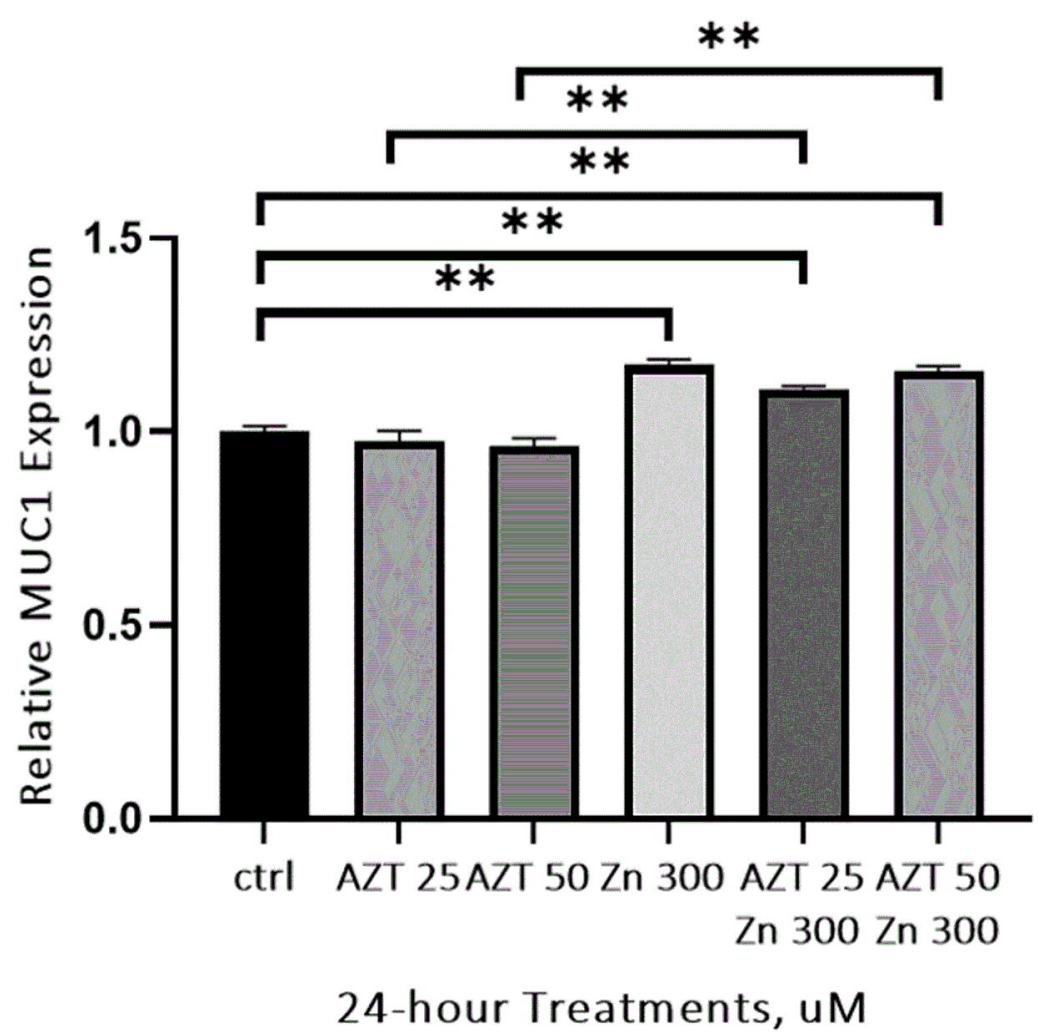

